\title{
RESOURCE CURSE AND THE EITI MEMBERSHIP EFFECT ON THE ECONOMIC GROWTH AND CORRUPTION IN SUB-SAHARAN AFRICA: PART I - A THEORETICAL REVIEW
}

\author{
Andries Francois Geldenhuys ${ }^{1}$, Oluseye Samuel Ajuwon ${ }^{2 *}$, Michael Graham ${ }^{1}$ \\ ${ }^{1}$ Business School, Stellenbosch University, Western Cape, South Africa \\ ${ }^{2}$ Department of Economics, University of Lagos, Lagos, Nigeria \\ fgeldenhuys46@gmail.com \\ aajuwon@unilag.edu.ng \\ michael.graham@usb.ac.za
}

\begin{abstract}
This study reviews the theoretical literature concerning the resource curse as it pertains to the impact of natural resources upon economic growth and corruption in subSaharan Africa (SSA), and how the Extractive Industries Transparency Initiative (EITI) membership can be of help. The EITI is an international standard promoting open and transparent resource governance through disclosure mechanisms in the resource value chain. Corruption has been associated with less-than-average economic growth in resourcerich countries. This research concludes that the theoretical review found that through the dissemination of disclosures in the natural resource sector, the EITI can potentially reduce the prevalence of corruption in implementing countries in SSA and it can address negative economic growth outcomes associated with resource abundance. However, there is not much evidence empirically needed to suggest this.
\end{abstract}

Keywords: Extractive Industries Transparency Initiative (EITI), corruption, transparency, resource curse, economic growth.

JEL Classification: 013.

\section{Introduction}

This study is set out to determine if natural resource income and expenditure information disclosure to civil society organisations, through EITI membership, will increase economic growth, and impact corruption positively in sub-Saharan African Countries. The question of what distinguishes resource-rich states, like Norway (oil) and Botswana (diamonds), from basket-case economies (economy characterized by high level of unemployment, and all economic woes), like Venezuela (oil) and Sierra Leone (diamonds), has been investigated in specialty literature. The available studies suggest that corruption, which is highly susceptible in extractive industries, plays a prominent role in explaining the divergent fortunes of such resource-rich states (Fisman and Golden, 2017). A thread of studies examining the relationship between corruption and economic growth, however, argues that corruption can be economically justified if it allows the private sector to bypass inefficient regulations and red tape. By greasing the wheels, corruption overcomes the distortions created by ill-functioning institutions (Leff, 1964; Huntington, 1968; Leys, 1965). The empirical literature, which suggests a positive impact of corruption on economic growth, is, however, inconsistent with the efficient corruption hypothesis and confirms the 'sand the wheels' hypothesis (Méon and Sekkat, 2005). This literature has, seemingly, reached a consensus on the reported negative impact of corruption on economic growth through its

* Corresponding author: Oluseye Samuel Ajuwon 
impact on investment and governance indicators (Mauro, 1995; Brunetti and Weder, 1998; Kauffman and Wei, 2000; Mo, 2001; Méon and Sekkat, 2005).

The specialty literature has recently evolved from viewing corruption as being a primarily principal-agent problem, towards seeing it as more of a collective action problem (MungiuPippidi, 2015; Kossow and Kukutschka, 2017). This collective action problem necessitates the involvement of civil society organisations (CSOs), which have been found to be key in controlling corruption. The Extractive Industries Transparency Initiative (EITI) offers citizens a tool to enforce accountability in the natural resource sector through transparency in the resource value chain, including revenue disclosures, licensing and contracting processes and contributions to fiscal budgets. The EITI has been strongly promoted in development circles as an instrument that can enable resource-abundant countries to transform their potential endowment wealth into social and economic prosperity (Ölcer, 2009). Using multistakeholder groups (MSGs), including civil society, this global standard can, potentially, address the collective action problems in resource corruption and disaffirm the negative effects of natural resource abundance.

This study argues that through the dissemination of disclosures in the natural resource sector, the EITI can potentially reduce the prevalence of corruption in implementing countries in SSA and address negative economic growth outcomes associated with resource abundance. First, it is suggested that natural resource information disclosure to civil society organisations, through EITI membership, would reduce corruption on resource endowment in a member country. It is expected that corruption will be reduced by the mobilisation of a collective action, led by CSOs having access to information, which could enhance public demand for accountability. In addition, economic growth is expected to increase because of less resource misallocation, a reduction in rent-seeking opportunities, lower inefficient taxes on businesses, and less distortion in decision-making processes. Transparency in tax revenue and budget allocation could also increase social spending that enhances human development and positively affects economic growth. The focus on SSA is based on the region having the lowest average score on the 2017 Resource Governance Index, 43 out of 100. The assessment criteria of value realisation, revenue management, enabling environment and law and practice indicate the current weaknesses in resource governance in SSA (NRGI, 2017). The region also scores particularly low on revenue management, one of the main aims of the EITI. Thus, it provides fertile grounds to give empirical validation of the impact of EITI membership on the resource curse, corruption, and economic growth nexus. The paper focuses on both the indirect and direct effects of country membership of $\mathrm{EITI}$ on economic growth. The indirect effect is informed by the literature on the correlation between high corruption and low economic growth, and the ability of transparency to reduce corruption through collective action. The EITI is expected, through its involvement in civil society, to reduce corruption in resource-rich states in SSA, and therefore indirectly address the resource curse. It is also thought that transparency could increase economic growth without reducing corruption. By signing up to the standard, governments send a signal to investors that they are committed to reforms. Without directly addressing corruption, the country could still benefit from increased foreign inflows. Evidence from the existing literature suggests that countries that implement the EITI have been able to attract additional foreign aid, with membership enhancing the reputation of the state's commitment to good governance (David-Barret and Okamura, 2013). EITI disclosures could reduce the risk of illicit financial flows, as citizens can see how much their governments are being paid for local resources (Ernst, 2013). This monitoring could ensure that more resource funds remain within the host country, even if local corruption is not directly reduced.

This paper contributes to the literature on whether transparency, through collective action, is an effective tool to curb corruption and consequently improve economic growth. The rest 
of the paper is structured as follows: Section 2 presents the literature review. Section 3 concludes the study.

\section{Literature Review}

\subsection{Theoretical Literature Review \\ 2.1.1. Resource Curse}

Theoretical literature distinguishes between the direct and indirect effects of natural resources on economic growth. The direct effect, commonly known as Dutch disease, relates to an appreciation in the real exchange rate of a country due to the inflow of substantial amounts of foreign currency (Sachs and Warner, 2001). This appreciation establishes equilibrium in the labour and non-traded goods market as increased disposable income raises the wages in the non-traded goods sector, and it increases the demand for non-traded goods. The traded non-resource goods sector loses competitiveness as it is partially crowded out (spending effect) (Leite and Weidmann, 1999). Secondly, the increased wages in the resource sector during a resource boom pull capital and labour away from other sectors (resource pull effect) (Leite and Weidmann, 1999). Entrepreneurial activity and innovation are crowded out by sectoral wage levels as labour gravitates to the resource sector (Sachs and Warner, 2001).

The indirect effect is manifested in rent-seeking governance (Leite and Weidmann, 1999). Extractive resource industries are believed to generate rents as 'a matter of course', which seems to be damaging (Collier, 2007; Collier and Goderis, 2007). These rents are unearned income from wealth, as they are not a result of normal production but rather a transformation of wealth from nature to financial (Holden, 2013). The windfall received by government, through the inflow of investment in the resource sector, creates a 'feeding frenzy' in which competing groups fight for resource rents at the expense of public goods (Khan, 1994). Ross (2001) argues that resources create a 'rentier effect', as governments are funded by resource wealth, instead of citizen taxation. The 'taxation effect' reduces incentives for citizen engagement and budget accountability, as state funds are not drawn from the populace, which potentially causes apathy towards the workings of the government. The direct and indirect effects are connected by Torvik (2001), who argues that in a rent-seeking model with abundant natural resources, the number of entrepreneurs engaged in rentseeking reduces productive-sector entrepreneurs and therefore reduces income and welfare. This view is supported by Fisman and Golden (2017), who state that in societies aroused with government-controlled resources, the most profitable opportunities for moguls might be through government rather than commerce, as it becomes easier to skim off the top or receive kick-backs. It is also theorised that governments that earn substantial resource through rents are less likely to introduce structural reforms, invest in growth supporting public goods, liberalise their economies and choose more protective trade policies (Sachs and Warner, 1995).

\subsubsection{Corruption and Economic Growth}

The theoretical literature offers two contrasting views on the effect of corruption on economic growth; the 'grease the wheels' and 'sand the wheels' hypotheses. The 'grease the wheels' hypothesis states that corruption can cancel out the negative effect of an inefficient bureaucracy and excessive red tape, increasing economic efficiency (Leff, 1964; Huntington, 1968). Liu (1985) argues that bribes rearrange the queuing process, allocating time efficiently, by moving those to whom time is more valuable to the front of the line. Corruption could also ensure that projects are awarded to the most efficient firms that stand to gain the most by paying the highest bribe (Beck and Maher, 1986). However, this view 
contrasts with the 'sand the wheels' hypothesis, whereby corruption reduces economic efficiency and has a detrimental effect on economic growth (Méon and Sekkat, 2005).

There are five main transmission channels through which corruption can negatively affect economic growth (Chêne, 2014). Firstly, at the macro-level, market forces and incentives can become distorted, resulting in the misallocation of resources. Kurer (1993) argues that corrupt officials have incentives to create additional distortion in the economy in order to preserve the illegal outcomes they benefit from. The firms that can pay the highest bribes and obtain the required licensing might not be efficient users of available resources. These firms may only be able to afford the bribe at the expense of the quality of their products (Rose-Ackermann, 1997). Secondly, corruption drives talent and resources towards rentseeking and away from productive activities. Baumol (1990) argues that the reallocation of talent from productive to rent-seeking activities reduces efficiency in the economy and lowers economic growth. As the returns on rent-seeking increase, private investment is crowded out (Murphy, Shleifer and Vishny, 1993). Mehlum, Moene and Torvik (2006) make a distinction between "producer-friendly" institutions, where rent-seeking and producing activities are aligned, and "grabber-friendly" institutions where rent-seeking is prioritised at the expense of producing activities. "Grabber-friendly" institutions are bad for growth in resource-rich states as they divert potentially productive entrepreneurs away from producing activities. These institutions are characterised by weak rule of law, corruption and inefficient governance that exposes the state to the resource curse.

Thirdly, at the firm level, corruption levies an inefficient tax on business which raises production costs. Boycko, Shleifer and Vishny (1995) argue that the uncertainty around the enforceability of corrupt contracts increases the enforcement costs for the firms. The illegality of bribery, directs efforts towards avoiding punishment and detection, resulting in corruption becoming more distortionary than taxation (Shliefer and Vishny, 1993). Fourthly, corruption is expected to decrease the productivity of firms and government investments. Tanzi and Davoodi (1997) theorise that corruption distorts the decision-making process on public investment, leading to a distortion in capital budgets and thus lowering return on investment. Public officials are expected to customise their requests by charging firms according to their ability to pay. The nature and amount of the harassment are intended to maximise the pay-out, reducing the firm's productivity by increasing red tape (Kauffman and Wei, 2000). Lastly, rent-seeking is expected to undermine public expenditure. Ugur and Dasgupta (2011) argue that corruption has indirect negative effects on investment and human capital, subsequently lowering the efficiency of public expenditure. Corruption reduces the resources available for human development spending and maintenance of existing infrastructure and results in inferior-quality infrastructure that will have to be rebuilt (Tanzi and Davoodi, 1997).

Natural resources play a key role in the ability of a state to control corruption. An equilibrium model developed by Mungiu-Pippidi (2015) states that to control corruption the constraints (legal and normative) must exceed the opportunities (power discretion and resources). The ability of natural resources to be turned into spoils or to generate rents increases the opportunities for corruption, especially when discretionary power structures are in place, for example monopolies, cartels and patronage networks (Mungiu-Pippidi, 2015). Not only are natural resources considered to foment corruption, but corruption can also create a vicious circle where natural resources become detrimental to economic growth (Fisman and Golden, 2017).

\subsubsection{Transparency and Corruption}

The use of transparency initiatives is viewed as a key element in the fight against corruption in resource-rich states (Kolstad and Wiig, 2008). These initiatives seek in general to improve the sanctioning mechanisms through which civil society can hold governments accountable 
and enhance the development outcomes when natural resources are abundant (Mejía Acosta, 2013). Transparency is expected to open the lines of communication, allow scrutiny of government rents and theoretically incentivise governments to invest in pro-development policies (Corrigan, 2013; Nwapi, 2014). Traditional transparency theory is based on a simplistic model that assumes that information released will produce an engaged and informed citizenry that is motivated to hold government to account (Fenster, 2005).

The prevalence of corruption has historically been considered a principal-agent problem (Mungiu-Pippidi, 2015). A functioning principal-agent theory between citizens (principals) and government (agents) is dependent on the principal having access to information about the agent's actions and holding the agent accountable by elections (Kolstad and Wiig, 2008). However, the agency problem suffers from information asymmetry when there is limited transparency, which sets the stage for rent-seeking governance. In a theoretical model, Klitgaard (2000) states that corruption (C) is the product of monopoly power (M) plus discretion (D) minus accountability $(A)$ : $(C=M+D-A)$. One of the proposed solutions to enhance accountability in the equation is to increase transparency. The problem is that the principal that is needed to enforce this accountability is seldom there. Even if the principal is easy to find, Pitlik et al (2010) argue that disclosed information must be on the principal's account, through societal accountability, to have a sanctioning effect. This theory is supported by Lindstedt and Naurin (2010), who argue that non-agent transparency is more effective in reducing corruption than transparency controlled by the agent. Solving the principal-agent problem was attempted by establishing laws that asked for greater transparency to help citizens hold government to account (Klitgaard, 1988).

Recently, anti-corruption scholars have started to move away from viewing corruption as a principal-agent problem to seeing it as a collective action problem (Kossow and Kukutschka, 2017). Mungiu-Pippidi (2015) argues that transparency can reduce corruption opportunities by reducing power discretion and increasing normative constraints on corruption through civil society engagement and collective action. The involvement of civil society is crucial to collective action in the fight against corruption. The EITI, with its multi-stakeholder approach and dissemination of resource information, should theoretically be a helpful tool in controlling corruption through its impact on administrative discretion, a major resource for corruption, and mobilising the public to act collectively and increase the normative constraints on the state. Substantive benefits from transparency in the natural resource sector are expected in the form of less corruption and fraud, equitable revenue distribution and a reduction in conflict. Procedural and normative benefits are expected through the empowerment of civil society, which can hold governments and corporations accountable in other spheres of the economy (Haufler, 2010).

Transparency on its own is unlikely to be sufficient to reduce corruption in the natural resource sector. Lindstedt and Naurin (2010) argue that transparency effectiveness depends on the complementary conditions of "publicity" and "accountability", where information is communicated to the public and the public moves from awareness to action. The EITI aims to ensure the "publicity" of resource information and ensure CSOs to enforce accountability measures through the collective action of an engaged citizenry. There are three spheres of accountability: vertical, through elections; horizontal, through checks and balances; and societal, through the free press and civil society (Kolstad and Wiig, 2016). The EITI can be a tool that enhances the horizontal and societal spheres, which could ultimately also contribute to vertical accountability as the principal becomes more engaged by transparency in the resource sector. Transparency can however also have adverse effects and increase corruption if the identification effect (identifying bribing channels through information disclosure) dominates the detection effect (the probability of being caught) (Kolstad and Wiig, 2008). CSOs engagement in increasing the detection effect is 
crucial and depends heavily on the dissemination of information, mobilising the citizenry to remain vigilant.

Theoretical literature provides support for institutional transparency in the natural resource sector. Through disseminated disclosures, CSOs are expected to address collective action problems and mitigate the negative effects of resource abundance. In theory the resource curse is manifested directly through misallocation of resources and indirectly through the prevalence of rent-seeking governance, which reduces the incentives for structural reforms. Disclosures to CSOs are vital to hold rent-seeking governments to account. Corruption negatively affects economic growth through multiple transmission channels. Resource abundance can also be used to hamper the fight against corruption, ultimately creating a vicious circle between resource abundance, corruption and slow growth. Transparency is theorised to produce an engaged citizenry that will hold government to account through checks and balances. However, the principal-agent problem is manifested through information asymmetry that makes accountability difficult; at the very least, information disclosures should be on the principal's account. Increasingly collective action, through CSO engagement, is expected to address accountability concerns by mobilising citizens to act. This further underline the importance of institutional transparency in the natural resource sector, which can be used by CSOs to increase checks and balances on corrupt governments.

\subsection{Empirical Literature Review \\ 2.2.1. Resource Curse}

The debate on whether natural resource abundance is detrimental to economic growth was ignited by a seminal paper by Sachs and Warner (1995). The authors argued that there is an inverse relationship between natural resource intensity and economic growth. The finding was based on cross-country growth regressions for 95 developing countries from 1970 to 1990. This theory was expanded by Sachs and Warner (2001), who tested the same data set for omitted geographical and climate variables. Little direct evidence was found that climate and geography explained the curse, and the "Dutch disease" hypothesis was strengthened by the tendency of resource-abundant countries to be high-priced economies. These findings were supported by Karl (1997) and Ross (1999), who found that oil-rich countries have declining income per capita and displayed lower development outcomes.

The cross-country research agenda has subsequently lost its intensity, as results have been found to hold only under specific circumstances. The results only hold for non-democratic nations; the pattern is prevalent for some resources and not for others; longer time periods turn up little evidence; and the control variables used. For example, income play a significant role (Fisman and Golden, 2017). Alexeev and Conrad (2005) have criticised the resource curse findings due to the use of initial GDP per capita when resources were discovered as a control variable, which biases the results towards a negative effect of natural resources on institutions. This is due to GDP per capita increasing when new resources are discovered, without a simultaneous increase in institutional quality. A negative coefficient is therefore assigned to resource wealth, as these newly resource-rich countries are measured against resource-poor countries where quality institutions are positively related to GDP. The authors ran 2SLS regressions on 82 countries from 1970 to 2000. The study concludes that there was little or no evidence that resource abundance slowed economic growth; in fact, it claims that resource abundance increases economic growth. Isham et al (2005), using a 3SLS model for 90 countries from 1975 to 1997, only supported the Sachs and Warner hypothesis for point-source resource exports, metals and fuel, and found no resource curse for plantation resources. Sala-i-Martin and Subramanian (2003), using an instrumental variable estimation strategy for 82 countries from 1960 to 2000, found that controlling for institutional quality, natural resource abundance has little or no effect on economic growth. Case studies 
and micro-economic analyses of country-level risks have been found to be more useful than cross-country studies, especially those examining how resource abundance affects corruption and ultimately growth (Fisman and Golden, 2017).

\subsubsection{Corruption and Economic Growth}

The empirical evidence on the detrimental effect of corruption on economic growth has largely reached consensus and rejected the "grease the wheels" argument in favour of the "sand the wheels" hypothesis. Cross-country data indicates that corruption is consistently correlated with lower growth and lower GDP per capita (Rothstein and Holmberg, 2011). The theoretical arguments of the negative effect of corruption on economic growth through lower levels of investment, lower quality of investments, high indirect taxation and the misallocation of resources are largely supported by empirical studies (Dimant and Tosato, 2017).

Mauro (1995) found that corruption lowered investment, lowered the investment ratio to GDP and subsequently inhibited economic growth in corrupt economies from 1960 to 1990 . This finding is supported by Wei (2000), using a sample of 12 source countries and 45 host counties, who found that corruption is a significant factor in reducing foreign direct investment in a host nation. Corruption has been found to lower capital productivity by up to 4 per cent and reduce net annual capital inflows by 0.5 per cent of GDP (Lambsdorf, 2003). Tanzi and Davoodi (2001) provide evidence for the relationship between corruption and the misallocation of talent to unproductive activities and higher levels of indirect taxation, subsequently reducing economic growth.

Ugur and Dasgupta (2011) in a systemic review of the available evidence, report that corruption has a negative effect on growth in low-income countries. The authors found that in these countries a one-unit increase in the perceived corruption index is associated with a 0.59 percentage-point decrease in economic growth. Countries with high levels of corruption have also been found to generate large shadow economies, which tend to be less efficient and grow at the expense of the official economy (Dreher and Herzfeld, 2005). Leite and Weidmann (1999), using a simple growth model, illustrated the relationship between resource abundance, corruption and economic growth. The authors found that natural resources are positively associated with corruption. The transmission channel for this association is the earning of hard currency that provides the opportunity for rent-seeking. Capital-intensive resources are found to be major determinants of corruption, and corruption is an important explanation for slow economic growth in resource-rich states (Leite and Weidmann, 1999).

\subsubsection{Transparency and Corruption}

The empirical literature shows that increased transparency can reduce corruption, albeit with some caveats, and that transparency on its own does not automatically lead to increased accountability and reduced corruption. Islam (2006), observing 169 countries from 1984 to 1997 , found that increased information flows (higher transparency) on economic data led to better governance indicators. Bauhr, Grimes and Harring (2010) found that increased transparency generated different reactions in countries with higher levels of corruption to those with lower levels. In highly corrupt countries, transparency erodes political trust but stimulates civic engagement. The incitement of civic discontent in the short term is however mitigated by greater accountability and better governance in the long term.

In a cross-country study of 111 states from 1972 to 2004, Lindstedt and Naurin (2010) found that making political institutions more transparent was indeed an effective tool in fighting corruption. However, the authors stress the importance of complementary conditions such as accountability and publicity, without which transparency has limited effects on reducing corruption. Non-agent-controlled transparency, such as a free press and CSOs, was found 
to have a greater effect on reducing corruption, highlighting the importance of CSOs supporting citizens to act once information is released. Kolstad and Wiig (2009) introduced transparency as an explanatory variable in the Sachs and Warner (1997) dataset. The authors found that increased transparency can reduce corruption, but only under specific circumstances. There must be incentives for agents to act on the information, along with the ability to process the information. The authors emphasise the need for an educated electorate and strong civil society that has the power to hold government accountable.

Increased transparency has also been found to have potential negative outcomes. Bauhr and Grimes (2013) found that increased transparency in highly corrupt countries tends to result in resignation and withdrawal from political life, rather than indignation and motivation to act. Transparency in these contexts suffers from a principal-agent breakdown, as there are limited effective sanctioning mechanisms available to the principal. Collective action concerns also arise, as standard game theory suggests that the individual's incentive to invest resources in collective endeavours depends on evidence that others will do the same. The role of CSOs is crucial here, as they can mobilise action on behalf of individuals, overcoming these collective-action constraints, and ultimately benefit society as a whole. Bac (2001) found that more transparency does not necessarily imply less corruption. This occurs when the "connection effect" (the ability to identify corrupt officials with whom to build relationships) dominates the probability of detection, resulting in local transparency potentially increasing corruption.

Corrigan (2013) investigated the influence that membership of the EITI has on economic development and quality of governance, including an indicator for levels of corruption. Using OLS regressions on pooled cross-sectional panel data for 200 countries from 1995 to 2009 , the author found that institutional transparency mitigated the resource curse with reference to GDP per capita, facilitated limited improvement in corruption and accountability measures and showed no improvement in stability and violence indicators.

\section{Conclusion}

The use of transparency to negate corruption and encourage economic growth remains an important topic at the international fora and it is the subject of substantial empirical review. The EITI has been proposed as a practical way to use transparency as a measure to reduce the negative effect of resource abundance. The theoretical review found that through the dissemination of disclosures in the natural resource sector, the EITI can potentially reduce the prevalence of corruption in implementing countries in SSA and address negative economic growth outcomes associated with resource abundance. First, it is suggested that natural resource information disclosure to civil society organisations, through EITI membership, would reduce corruption on resource endowment in a member country. It is expected that corruption will be reduced by the mobilisation of collective action, led by CSOs having access to information, which could enhance public demand for accountability. In addition, economic growth is expected to increase because of less resource misallocation, a reduction in rent-seeking opportunities, lower inefficient taxes on businesses, and less distortion in decision-making processes. While empirical literature could not agree on the resource curse, there is a consensus on the negative impact of corruption on economic growth, and that transparency can help to reduce corruption but with a caveat. There is therefore a need to conduct an empirical analysis on EITI membership effect on economic growth and corruption reduction in sub-Saharan Africa. 


\section{References}

Alexeev, M. and Conrad, R. 2005. The elusive curse of oil. The Review of Economics and Statistics, 91 (3), pp. 586-598.

Bac, M. 2001. Corruption, connections and transparency: Does a better screen imply a better scene? Public Choice, 107, pp. 87-96.

Bauhr, M. and Grimes, M. 2013. Indignation or resignation: The implications of transparency for societal accountability. Governance: An International Journal of Policy, Administration, and Institutions, 27 (2), pp. 291-320.

Bauhr, M., Grimes, M. and Harring, N. 2010. Seeing the state: The implications of transparency for societal accountability. Gothenburg: Quality of Government Institute Working Paper Series 2010:15.

Baumol, W.J. 1990. Entrepreneurship: Productive, unproductive and destructive. Journal of Political Economy, 98 (5), pp. 893-921.

Beck, P.J. and Maher, M.W. 1986. A comparison of bribery and bidding in thin markets. Economics Letters 20, pp. 1-5.

Boycko, M., Shliefer, A. and Vishny, R. 1995. Privatizing Russia. Cambridge, MA: MIT Press. Brunetti, A. and Weder, B. 1998. Investment and institutional uncertainty: A comparative study of different uncertainty measures. Weltwirtschaftliches Archiv, 134, pp. 513-533.

Chêne, M. 2014. The impact of corruption on growth and inequality. Berlin: Transparency International.

Collier, P. 2007. The bottom billion: Why the poorest countries are failing and what can be done about it. Oxford: Oxford University Press.

Collier, P. and Goderis, B. 2007. Commodity prices, growth, and the natural resource curse: Reconciling a conundrum. Oxford: University of Oxford.

Corrigan, C.C. 2013. Breaking the resource curse: Transparency in the natural resource sector and the extractive industries transparency initiative. Resources Policy, 40, pp. 17-30. David-Barret, L. and Okamura, K. 2013. The transparency paradox: Why do corrupt countries join EITI? ERCAS Working Paper No. 38. Berlin: European Research Centre for Anticorruption and State-Building.

Dimant, E. and Tosato, G. 2017. Causes and effects of corruption: What has the past decade's empirical research taught us? A survey. Journal of Economic Surveys, pp. 1-22.

Dreher, A. and Herzfeld, T. 2005. The economic costs of corruption: A survey and new evidence. Public Economics 0506001, University Library of Munich, Germany.

EITI International Secretariat. 2017. https://eiti.org/ Accessed on 23 July 2017.

Ernst, J. 2013. Extractive Industries Transparency Initiative: Results profile. World Bank.

Fenster, M. 2005. The opacity of transparency. lowa Law Review 91 (3), pp. 885-949.

Fisman, R. and Golden, M.A. 2017. Corruption: What everyone needs to know. New York: Oxford University Press.

Haufler, V. 2010. Disclosure as governance: The Extractive Industries Transparency Initiative and resource management in the developing world. Global Environmental Politics, 10 (3), pp. 53-73.

Holden, S. 2013. Avoiding the resource curse: The case of Norway. Energy Policy 63:870876. Department of Economics. University of Oslo.

Huntington, S.P. 1968. Political order in changing societies. New Haven: Yale University Press.

Isham, J., Woolcock M., Pritchett, L. and Busby, G. 2005. The variety of resource experience: How natural resource export structures affect the political economy of economic growth. Middlebury College Economics Discussion Paper No. 03-08R.

Islam, R., 2006. Does more transparency go along with better governance? Economics and Politics, 18 (2), pp.121-167. 
Karl, T. L. 1997. The paradox of plenty: Oil booms and petro-states. Berkeley and Los Angeles: University of California Press.

Kaufmann, D. and Wei, S.-J. 2000. Does 'grease money' speed up the wheels of commerce? International Monetary Fund Policy Working Paper WP/00/64.

Khan, A. 1994. The political economy of oil. Oxford: Oxford University Press.

Klitgaard, R. 1988. Controlling corruption. Berkeley: University of California Press.

Klitgaard, R. 2000. Corrupt cities: A practical guide to cure and prevention. Washington DC: World Bank Institute.

Kolstad, I. and Wiig, A., 2009. Is transparency the key to reducing corruption in resourcerich countries? World Development, 37 (3), pp.521-532.

Kolstad, I. and Wiig, A. 2016. Does democracy reduce corruption? Democratization, 23 (7), pp. 1198-1215.

Kossow, N. and Kukutschka, R.M.B. 2017. Civil society and online connectivity: Controlling corruption on the net? Crime, Law and Social Change, 68, pp. 459-476.

Kurer, O. 1993. Clientelism, corruption and the allocation of resources. Public Choice, 77, pp. 259-273.

Lambsdorff, J.G. (2003). How corruption affects persistent capital flows. Economics of Governance, 4, pp. 229-243, https://doi.org/10.1007/s10101-002-0060-0.

Leff, N.H. 1964. Economic development through bureaucratic corruption. American Behavioral Scientist 8:8-14. Reprinted in A.J. Heidenheimer, M. Johnston and V.T. LeVine (Eds) 1989. Political corruption: A handbook. Oxford: Transaction Books, 389-403.

Leite, C.A. and Weidmann, J. 1999. Does Mother Nature corrupt? Natural resources, corruption and economic growth. Working Paper WP/99/85. International Monetary Fund.

Leys, C. 1965. What is the problem about corruption? Journal of Modern African Studies, 3, pp.215-230. Reprinted in A.J. Heidenheimer, M. Johnston and V.T. LeVine (Eds)1989. Political corruption: A handbook. Oxford: Transaction Books, 51-66.

Lindstedt, C. and Naurin, D. 2010. Transparency is not enough: Making transparency effective in reducing corruption. International Political Science Review 31 (3), pp. 301-322. Liu, F.T. 1985. An equilibrium queuing model of bribery. Journal of Political Economy, 93, pp. 760-781.

Mauro, P. 1995. Corruption and growth. Quarterly Journal of Economics, 110 (3), pp. 681712.

Mehlum, H., Moene, K. and Torvik, R. 2006. Institutions and the resource curse. The Economic Journal, 116, pp. 1-20.

Mejía Acosta, A. 2013. The impact and effectiveness of accountability and transparency initiatives: The governance of natural resources. Development Policy Review. 31, pp. 89105, https://doi.org/10.1111/dpr.12021.

Méon, P. and Sekkat, K. 2005. Does corruption grease or sand the wheels of growth? Public Choice, 122, pp. 69-97.

Mo, P.H. 2001. Corruption and economic growth. Journal of Comparative Economics, 29, pp. 66-79.

Mungiu-Pippidi, A. 2015. The quest for good governance: How societies develop control of corruption. Cambridge: Cambridge University Press.

Murphy, K., Shleifer, A. and Vishny, R. 1993. Why is rent-seeking so costly to growth? American Economic Review 83 (2), pp. 409-414.

Natural Resource Governance Institute (NRGI). 2017. Resource Governance Index. http://www.resourcegovernanceindex.org/ Accessed on 25 May, 2018.

Nwapi, C. 2014. Enhancing the effectiveness of transparency in Extractive Resource Governance: A Nigerian case study. Law and Development Review, 7 (1), pp. 23-47.

Ölcer, P. 2009. Extracting the maximum from the EITI. OECD Development Center Working Paper No. 276. 
Pitlik, H., Frank, B. and Firchow, M. 2010. The demand for transparency: an empirical note. Review of International Organizations, 5 (2), pp. 177-195.

Rose-Ackermann, R. 1997. The political economy of corruption. In K.A. Elliott (Ed.). Corruption and the global economy. Washington DC: Institute for International Economics, pp. $31-60$.

Ross, M. 2001. Does oil hinder democracy? World Politics, 53 (3), pp. 326-361.

Ross, M.L. 1999. The political economy of the resource curse. World Politics 51 (2), pp. 297-322.

Rothstein, B. and Holberg, S. 2011. Correlates of corruption. Working Paper Series 2011:12. The Quality of Government Institute.

Sachs, J.D. and Warner, A.M. 1995. Natural resource abundance and economic growth. Cambridge, MA: Centre for International Development and Harvard Institute for International Development.

Sachs, J.D. and Warner, A.M. 2001. The curse of natural resources. European Economic Review, 45 (4-6), pp. 827-838.

Sala-i-Martin, X. and Subramanian, A. 2003. Addressing the natural resource curse: An illustration from Nigeria. NBER Working Papers No. 9804. Cambridge, MA: National Bureau of Economic Research.

Shliefer, A. and Vishny, R. 1993. Corruption. Quarterly Journal of Economics, 108 (3), pp. 599-617.

Tanzi, V. and Davoodi, H. 1997. Corruption, public investment, and growth. International Monetary Fund Working Paper: WP/97/139.

Tanzi, V. and Davoodi, H. 2001. Corruption, growth and public finances. IMF Working Paper 182.

Torvik, R. 2001. Natural resources rent seeking and welfare. Journal of Development Economics 67, pp. 455-470.

Ugur, M. and Dasgupta, N. 2011. Evidence on the economic growth impacts of corruption in low-income countries and beyond. London: EPPI Centre, Social Science Research Unit, Institute of Education, University of London.

Wei, S.-J. 2000. Local corruption and global capital flows. Brookings Papers on Economic Activity 2, pp. 303-346.

\section{Bio-Note}

Geldenhuys Andries Francois (Mr) holds a Master's degree in Development Finance from the University of Stellenbosch Business School, South Africa, and works at Transparency International, a leading anti-corruption NGO, in Berlin, Germany. He is also a certified Chartered Accountant [CA(SA)].

Ajuwon Oluseye Samuel (Dr) is a lecturer of economics at the University of Lagos, Nigeria, with a PhD in Development Finance from the University of Stellenbosch Business School, South Africa. His area of research is in macroeconomics, international finance, and development finance, with a special focus on financing small businesses.

Graham Michael (Prof) is the Programme Head, Development Finance. He was previously Associate Professor of Finance at Stockholm Business School in Sweden before joining USB. Prof Graham's research interest lies in empirical corporate finance, corporate governance and financial markets. He teaches Corporate Finance, Structured Finance, Infrastructure Finance and International Finance and has extensive and international teaching experience, having taught in Australia, Finland and Singapore. 